OPEN ACCESS

Could anthropogenic soil erosion have influenced Mediterranean vegetation distribution over the Holocene?

To cite this article: Pamela M Collins et al 2010 IOP Conf. Ser.: Earth Environ. Sci. 9012011

View the article online for updates and enhancements.
Related content
- Response of terrestrial $\mathrm{N}_{2} \mathrm{O}$ and $\mathrm{NO}_{*}$, Mirjam Pfeiffer and Jed O Kaplan
- How different proxies record precipitation variability over southeastern South America
Cristiano M Chiessi, Stefan Mulitza, Jürgen Pätzold et al.
- Mid-late Holocene environments of Agua Buena locality (34⒌ $\left.50^{\prime} \mathrm{S} ; 69^{\circ} 56^{\prime} \mathrm{W}\right)$,
Mendoza, Argentina
Diego Navarro, A Mehl, M A Zarate et al.

\section{Recent citations}

$$
\frac{\text { A quantitative model for integrating }}{\text { landscape evolution and soil formation }}
$$


PAGES 1st Young Scientists Meeting (YSM) - 'Retrospective views on our planet's future' IOP Publishing IOP Conf. Series: Earth and Environmental Science 9 (2010) 012011 doi:10.1088/1755-1315/9/1/012011

\title{
Could anthropogenic soil erosion have influenced Mediterranean vegetation distribution over the Holocene?
}

\author{
P M Collins ${ }^{1}$, J O Kaplan and B A S Davis \\ Soil-Vegetation-Atmosphere Research Group ARVE, Institute of Environmental \\ Science and Technology, Ecole Polytechnique Fédéral de Lausanne, Station 2, 1015 \\ Lausanne, Switzerland \\ E-mail: pamela.collins@epfl.ch
}

\begin{abstract}
The circum-Mediterranean region is characterized by a strongly seasonal climate with rainy winters and intense summertime drought, steep topography, and a multi-millennial history of intensive human land use, all of which make its soils vulnerable to erosion. The historical and stratigraphic record documents severe and long-term soil erosion in several locations in the Mediterranean. A forest-to-scrub transition in Mediterranean vegetation between the mid-Holocene $(6,000 \mathrm{yr} \mathrm{BP})$ and the present is evident in the observational palaeorecord. Debate as to the causes of this shift is ongoing. This study seeks to test the sensitivity of large-scale vegetation patterns to changes in soil physical properties such as depth, content of coarse fragments, and organic matter content using the Mediterranean region as a case study. We find that simulated biomes are sensitive to changes in some soil physical properties at some locations, but that threshold values for soil change to affect vegetation are very high. Additional work is required to analyze the role that other soil physical properties, and climate change, played in influencing Holocene land cover change in the Mediterranean, and to improve model representations of relevant processes.
\end{abstract}

\section{Introduction}

Today, the lands bordering the Mediterranean Sea are largely characterized by coarse-textured shallow soils and sclerophyllous xeric vegetation [1]. Yet pollen records from the mid-Holocene $(6,000 \mathrm{yr} \mathrm{BP})$ suggest that several places currently dominated by xerophytic (drought-tolerant evergreen) vegetation once supported extensive deciduous forests [2,3]. Evidence suggests that the northern limit for xerophytic woodland and scrub in southern Europe was located up to three degrees of latitude farther south as compared to its present position [4]. The debate about the extent [5] and causes [6-8] of this observed northward expansion of xerophytic scrubland vegetation in the Mediterranean region between the middle and late Holocene is ongoing. Long-term changes in regional climate may have been the main driver, as orbitally forced changes in atmospheric circulation resulted in alterations in temperature [9] and precipitation [10] patterns in space and time and affected seasonal moisture regimes. Alternatively, the influence of changing human land use patterns may have played a role, as deforestation, grazing, crop cultivation, and use of fire exerted strong anthropogenic selection pressures on natural vegetation communities [11, 12]. As the combined effects of anthropogenic disturbance and climate change can dramatically alter soil moisture content by promoting soil erosion

\footnotetext{
${ }^{1}$ To whom any correspondence should be addressed.
} 
PAGES 1st Young Scientists Meeting (YSM) - 'Retrospective views on our planet's future' IOP Publishing IOP Conf. Series: Earth and Environmental Science 9 (2010) $012011 \quad$ doi:10.1088/1755-1315/9/1/012011

in uplands and sediment deposition in lowlands (for an overview, see [13]), our work attempts to contribute to this debate by posing the questions, "Do Mediterranean vegetation communities respond to changes in soil physical properties? If yes, how sensitive is the vegetation?"

Moisture availability often limits plant growth in seasonally arid environments such as the Mediterranean. Here, soils can play a prominent role in determining land cover by acting as moisture reservoirs during periods of drought [14]. Land cover and soil characteristics control the partitioning of precipitation into runoff and infiltration, and soil depth and texture influence the proportion of soil moisture lost to evaporation and drainage versus that retained in the soil matrix. Under identical climatic conditions, differences in soil depth and texture in adjacent patches can cause marked differences in vegetation density $[15,16]$ and species distribution [17].

Though modern Mediterranean upland soils tend to be coarse, shallow, and poor in organic matter content, evidence suggests that this was not always the case. The Global Assessment of Soil Degradation classifies the soils of much of the circum-Mediterranean region as moderately or severely degraded (approximately $97,000 \mathrm{~km}^{2}$ in Spain, 70,000 $\mathrm{km}^{2}$ in Italy, and $40,000 \mathrm{~km}^{2}$ in Greece [18]), with regions of very severe degradation $[18,19]$, implying that conditions were once quite different. During the classical periods of Greek and Roman civilization (ca. 2-3 ka BP), currently degraded landscapes such as those near ancient Carthage (Mediterranean north Africa) were once productive enough to feed cities and empires [20].

The combination of steep terrain, strongly seasonal and episodic precipitation, and a multimillennial history of continuous and often intensive human land use make the Mediterranean region particularly prone to upland erosion and lowland sedimentation. Alluvial stratigraphic records show several distinct events of elevated soil erosion throughout the Mediterranean during the Holocene; they vary in both duration and severity by location and may be correlated with fluctuations in both climate and regional civilizations [21, 22, 23] (for a review, see [13]).

Research programs such as ARCHAEOMEDES [24] and MEDALUS (Mediterranean Desertification and Land Use) [25] had the aim of qualitatively understanding land degradation in the Mediterranean on a regional or site-by-site basis in historical times and the present day, respectively. As yet, however, there has been no attempt to investigate the impact of changing soil depth and texture on vegetation cover across the Mediterranean region in a systematic, quantitative manner. This study does not attempt to explain the changes in Mediterranean land cover over the Holocene observed in the pollen record, nor does it intend to make comparisons between pollen-reconstructed and modelcalculated vegetation cover. Rather, it contributes to the ongoing debate about the causes of Mediterranean land cover change over the Holocene by testing the sensitivity of Mediterranean vegetation to changes in soil physical properties using a simple modeling approach.

\section{Methods}

To simplify our analysis and focus on those areas where we might expect changes in soil physical properties to have influenced vegetation cover in the past, we used the paleoecological record to identify a number of sites where vegetation changed from forest to non-forest types from the midHolocene to present. At 34 sites from across the Mediterranean region, we used the SoilMod soil physical model and the BIOME1 equilibrium vegetation model [14] to quantify the sensitivity of biome-scale vegetation to changing soil physical properties. The sites where we ran our model are broadly representative of the range of Mediterranean climate and soil characteristics, from mountains to coastlines and from semi-mesic to xeric environments. A detailed description of our methods follows.

\subsection{Site description}

The Mediterranean region lies roughly between $30^{\circ} \mathrm{N}$ and $40^{\circ} \mathrm{N}$ latitude and $10^{\circ} \mathrm{E}$ and $40^{\circ} \mathrm{W}$ longitude and has been defined as the region in which olive trees can be cultivated, the northern boundary of which is roughly determined by the $5^{\circ} \mathrm{C}$ January isotherm [26]. It is a tectonically young landscape with several steep mountain ranges. The climate is seasonal, with summers characterized by clear 
PAGES 1st Young Scientists Meeting (YSM) - 'Retrospective views on our planet's future' IOP Publishing IOP Conf. Series: Earth and Environmental Science 9 (2010) $012011 \quad$ doi:10.1088/1755-1315/9/1/012011

skies and drought due to the falling limb of the Hadley cell and winter weather dominated by the prevailing westerlies that deliver cyclonic precipitation with high spatial and temporal heterogeneity due to the varied topography. Average annual precipitation ranges from approximately 100 to $900 \mathrm{~mm}$ (two-thirds of which fall between September and March [1]), and the mean annual temperature is $15 \pm$ $5{ }^{\circ} \mathrm{C}[4]$.

\subsection{Data sources and study sites}

To identify specific sites that experienced a change in land cover between the mid-Holocene and the present, this study uses a published pollen-based reconstruction of Mediterranean land cover classified into 12 biomes (following [27]) at 122 sites for both the present day and the mid-Holocene [4]. We classified the biome assignment for each site for both time periods as forest or non-forest, according to each biome's annual moisture requirement index $\alpha$ (Priestly-Taylor coefficient, or ratio of actual to potential evapotranspiration, AET/PET) as described in [14] (forest: $1 \geq \alpha \geq 0.65$; non-forest: $0.65>\alpha$ $\geq 0$ ). Thirty-four sites shifted from forest to non-forest between $6 \mathrm{ka} \mathrm{BP}$ and the present (figure 1), 3 sites did the reverse, and 85 sites did not cross the $\alpha=0.65$ threshold in either direction. For each of the 34 sites that shifted from forest to non-forest, we extracted late 20th century soil data (depth, particle size distribution, organic matter content, percent of coarse fragments) at the $1 \mathrm{~km}$ gridcell nearest to each site from the Harmonized World Soil Database (HWSD) [28] and late 20th century mean climatology (temperature and precipitation values as used in [14]) from the WorldClim database [29]. The pollen data are not used again in this study after this site-selection step.

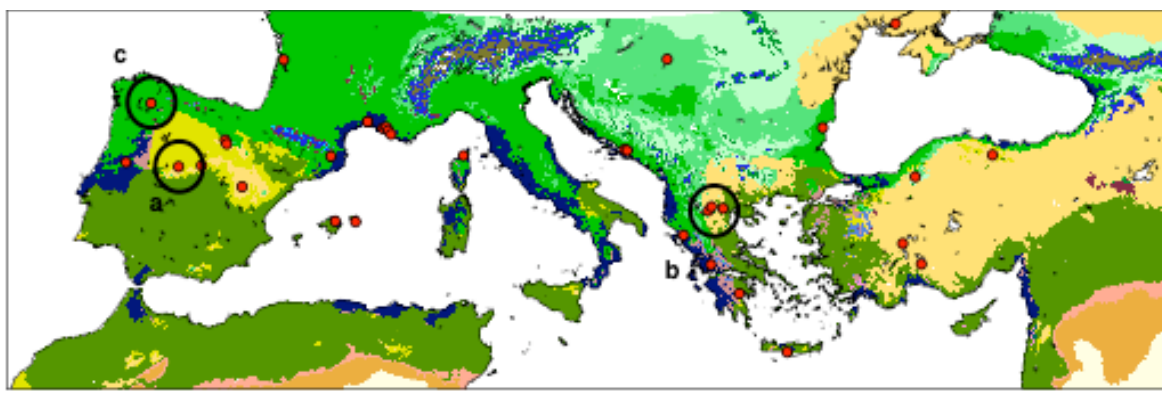

Figure 1. Potential natural vegetation of the Mediterranean study area simulated by the BIOME1 model. Each red circle represents a sediment core where pollen data indicate a forest biome at $6 \mathrm{ka} \mathrm{BP}$ and a non-forest biome in the present day [2]. Results for circled sites a, b, and c are presented in figures 2 and 3 .

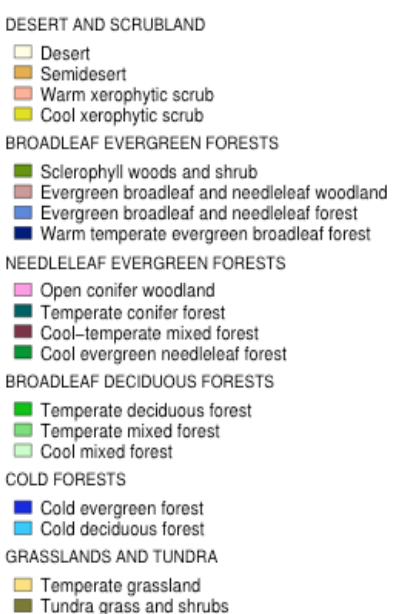

\subsection{Models and calibration}

We employed two models in this study. First, we used a soil physical model (SoilMod) driven by the HWSD parameters listed in section 2.2. This model consists of a series of pedotransfer functions [3034] and calculates soil bulk density, water holding capacity (defined as the difference between field capacity, or water remaining in the soil under $-33 \mathrm{kPa}$ water potential $[\Psi]$, and wilting point, or water remaining in the soil at $\Psi-1,500 \mathrm{kPa}$ ), and saturated hydraulic conductivity for the region surrounding each of the 34 sites analyzed.

Next, we used a global biogeography model (BIOME1) driven by WorldClim climate data [29] and the output from SoilMod (see above). For each gridcell or data point, BIOME1 uses these data to determine the presence or absence of each of 13 distinct plant functional types (PFTs) based on their physiological requirements, namely minimum and maximum thresholds of temperature and moisture availability [14]. The latter is determined by the moisture availability index $\alpha$, calculated as the ratio of actual to potential evapotranspiration (AET/PET) $[14,35]$. AET is proportional to soil water content in a single-layer "bucket" type soil, which is a function of soil water holding capacity (as calculated by 
PAGES 1st Young Scientists Meeting (YSM) - 'Retrospective views on our planet's future' IOP Publishing IOP Conf. Series: Earth and Environmental Science 9 (2010) $012011 \quad$ doi:10.1088/1755-1315/9/1/012011

SoilMod) and precipitation (from WorldClim). PET is calculated using the equations in [35] with temperature data from WorldClim and \% sunshine data from the CRU CL2.00 climatology [36]. Manipulating the soil physical properties for a given location changes the size of the soil "bucket" and therefore leads to a change in the calculated $\alpha$ value for that location, which in turn may alter the location's suitability for a given PFT. Finally, a unique biome name is assigned to each combination of present and absent PFTs (figure 1; PFTs as in [14]).

To calibrate BIOME1, we used it to generate a gridded map of potential natural vegetation represented as biomes (figure 1) and then refined our model parameterizations until the map output satisfactorily matched the modern potential vegetation distribution for the Mediterranean [37].

\subsection{Sensitivity tests}

As depth and content of coarse fragments (\% v) both influence the total volume of fine soil material that is available to retain water, and soil organic matter content $(\% \mathrm{w})$ affects a mineral soil's ability to retain water, these were the three soil physical parameters we chose to manipulate. Changing these three parameters alters the resulting bulk density, water holding capacity, and saturated hydraulic conductivity as calculated by SoilMod, which in turn modifies the $\alpha$ value used by BIOME1 to calculate the biome for each combination of parameters. Assuming that soil degradation would decrease depth and organic matter content and increase the percent of coarse fragments, we explored a wide range of parameter space that could represent both "degraded" and "improved" conditions relative to present-day soil conditions.

First, we varied the simulated depth of all soils from $0.1 \mathrm{~m}$ to $2.0 \mathrm{~m}$ and calculated soil water holding capacity using SoilMod, keeping all other soil characteristics constant. Then, we held depth constant at HWSD (present-day) values and simultaneously varied simulated soil organic matter from $0 \%$ to $20 \%(\mathrm{w})$ and content of coarse fragments (lithic material $>2 \mathrm{~mm}$ in diameter) from $100 \%$ to $0 \%$ (v) for all test sites, again using SoilMod. For both sets of experiments, we ran the new calculated soil bulk density, water holding capacity, and conductivity values through BIOME1 and checked the resulting simulated biome to see if a "degradation" or "improvement" in soil physical parameters under constant climatic conditions led to a change in the calculated biome assignment at any of our test sites.

\section{Results}

Of the 34 sites analyzed, the simulated biome was insensitive to any "improvement" in soil physical properties at all but three sites (figures 1,2,3). Each of these three sites was sensitive to a decrease in the content of coarse fragments, but only two were sensitive to an increase in depth, and none responded substantially to an increase in soil organic matter (figures 2, 3). Sensitivity was expressed by a change in the calculated biome for a site, e.g. from drought-tolerant open conifer woodland to drought-sensitive temperate deciduous forest (figures 2,3). 
PAGES 1st Young Scientists Meeting (YSM) - 'Retrospective views on our planet's future' IOP Publishing IOP Conf. Series: Earth and Environmental Science 9 (2010) 012011 doi:10.1088/1755-1315/9/1/012011

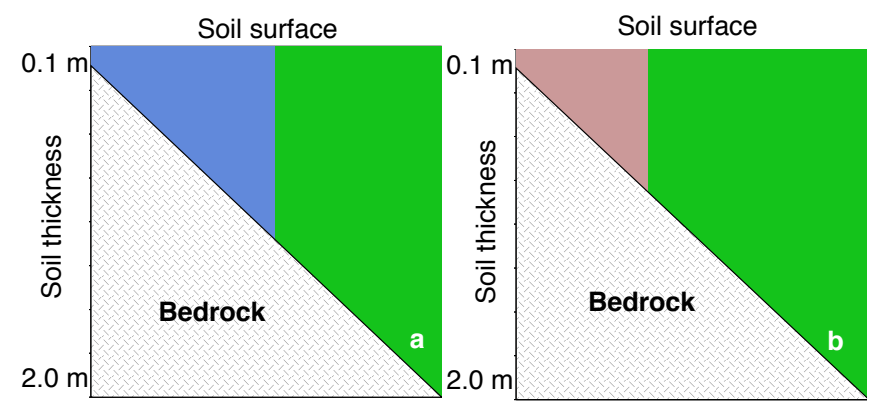

Figure 2. Increasing soil depth from $0.1 \mathrm{~m}$ to $2.0 \mathrm{~m}$ led to a biome shift at two of our 34 test sites. Letters correspond to circled sites in figure 1. Colors indicate biome types. Green: temperate deciduous forest; blue: evergreen broadleaf and needleleaf forest; rose: evergreen broadleaf and needleleaf woodland. For biome descriptions, see [14].

For this study, the majority of sites appear insensitive to increases in soil depth and organic matter and decreases in the content of coarse fragments. There are three potential explanations for this outcome: 1.) Changes may have occurred in the relative percentages of PFTs present, or even in levels of net primary productivity, but the resolution of our biome-level analysis was too coarse to pick up these subtleties; 2.) Soil water holding capacity is more sensitive to changes in soil texture (which we have not yet tested) than to soil depth, stoniness, or organic content; 3.) We tested the correct parameters and analyzed the output at the appropriate level of complexity, but in fact Mediterranean vegetation is insensitive to changes in soil physical properties.

The 3 sites that did respond to an "improvement" of soil physical properties were likely already near the threshold between two different biome classes (figure 1). However, all 34 sites responded to a "degradation" of soil physical properties; when soils approached a threshold level of 95\%-97\% (v) coarse fragments, biomes shifted uniformly to desert conditions.

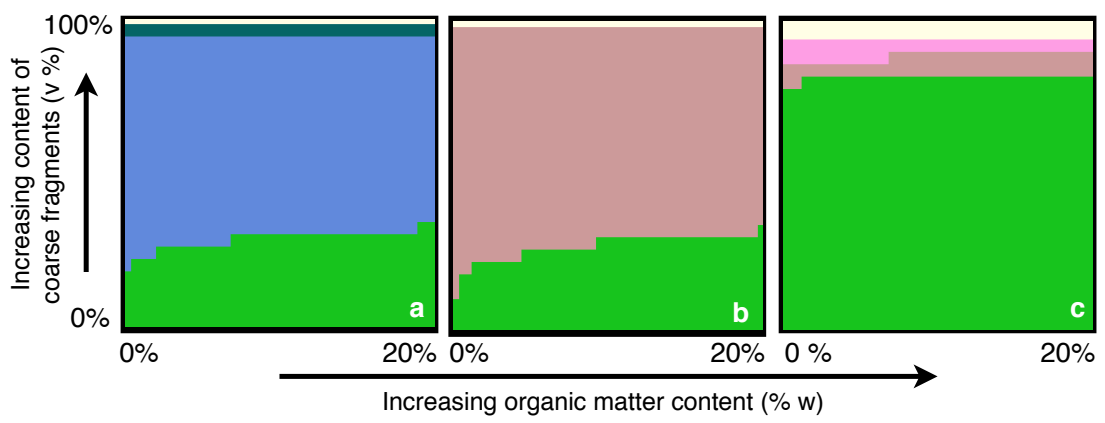

Figure 3. Changing soil organic matter content and content of coarse fragments caused a shift in simulated biome at three of our 34 test sites. Letters correspond to circled sites in figure 1. Change in color indicates biome shift. Pale Yellow: desert; dark green: temperate conifer forest; pink: open conifer woodland. For other colors, see figure 2.

Rather than analyzing the entire circum-Mediterranean region in a gridded manner, this study works with 34 individual points distributed across the entire region that are assumed to be representative of the full range of Mediterranean climate and soil characteristics. This was done to simplify our 
PAGES 1st Young Scientists Meeting (YSM) - 'Retrospective views on our planet's future' IOP Publishing IOP Conf. Series: Earth and Environmental Science 9 (2010) $012011 \quad$ doi:10.1088/1755-1315/9/1/012011

approach; we acknowledge that future work would benefit greatly from analyzing the entire gridded region and intend to do so in the future. The biome scheme used in BIOME1 is not analogous to the biome scheme used with the pollen data, making direct comparisons between biomes from model output and biome assignments from pollen data impossible. This discrepancy will be remedied in future work. For this study, we are more interested in whether or not a shift from one biome type to another occurs in response to changes in soil physical properties; the actual biome assignments are of secondary interest.

\section{Discussion and Conclusions}

Our results suggest that at least under certain circumstances, "improving" soils by increasing soil depth and organic matter content and/or decreasing the content of coarse fragments can lead to the simulation of more moisture-loving biome types (i.e. a shift from evergreen to deciduous vegetation) without requiring a change in climate, and reversing the direction of these changes can lead to the simulation of desert. However, the threshold levels for these changes are quite high and suggest that further study is required to improve our model representations of the processes involved in soilvegetation-climate interactions.

This study attempts to quantify the sensitivity of vegetation under Mediterranean conditions to soil thickness, stoniness, and organic matter content. Though all 34 sites analyzed demonstrate a clear transition from forest to non-forest biomes between the mid-Holocene and the present in the pollen record, only three respond to changes in modeled soil stoniness and organic matter content (figure 3), and just two of these show a change in biome in response to changing soil depth (figure 2). These results could suggest that Mediterranean vegetation is relatively insensitive to changes in soil physical properties. However, only a small number of soil parameters were tested for a limited number of locations, and more complex analysis over a wider area may reveal greater sensitivity.

We will follow up on this preliminary work with a more in-depth analysis of the environmental factors relevant at our study sites, and we will extend our analysis to additional sites. We will expand our experimental design to analyze soil texture (relative proportions of sand, silt, and clay), we will use an alternative soils dataset $[38,39]$ that provides more detailed information on soil depth at the present day, and we will analyze vegetation response at the levels of net primary productivity and plant functional types. We will also incorporate potential soil-climate feedbacks and interactions in future work.

The question of vegetation sensitivity to changes in soil physical characteristics is not merely academic. It may have serious implications for the concepts of sustainable land use and resilience of land to abuse and degradation. How much soil can be lost (or gained) before a region's natural vegetation community shifts from one stable state to another? Is the process reversible? Do thresholds differ between ecosystems? Though much work has been done on the annual to decadal detrimental effects of soil erosion on agricultural productivity [40-43], little quantitative data is available on how centuries or millennia of human land use alter the land's capacity to support natural vegetation or human activities. The circum-Mediterranean region is a drought-limited, seasonal environment prone to erosion that has been heavily used by humans for millennia. In many places, Mediterranean soils have experienced dramatic erosion since the mid-Holocene. The debate about what caused the observed shift in vegetation from forest to non-forest between the mid-Holocene and the present in many areas of the Mediterranean is still open. Any attempt to understand the dynamics of vegetation over long timescales should not ignore the potential impact of changes in soil physical properties under human, or even natural, influences.

\section{Acknowledgements}

Funding for this work was provided by grants from the Swiss National Science Foundation (PP0022_119049) and the Italian Ministry for Research and Education (FIRB RBID08LNFJ) for the Research Project CASTANEA. The authors also thank Dr. José Carrión and Dr. Paul Henne for their helpful comments on the manuscript of this paper. 
PAGES 1st Young Scientists Meeting (YSM) - 'Retrospective views on our planet's future' IOP Publishing IOP Conf. Series: Earth and Environmental Science 9 (2010) 012011 doi:10.1088/1755-1315/9/1/012011

\section{References}

[1] Breckle S-W 2002 Walter's Vegetation of the Earth: The Ecological Systems of the GeoBiosphere (Berlin: Springer)

[2] Bottema S 1980 Rev. Palaeobot. Palynol.31 193-217

[3] Jahns S 1993 Veget. Hist. Archaeobot. 2 187-203

[4] Roberts N, Stevenson T, Davis B, Cheddadi R, Brewster S and Rosen A 2004 in Battarbee R W et al. (eds) Past Climate Variability through Europe and Africa (Dordrecht: Springer)

[5] Grove A T and Rackham O 2003 The Nature of Mediterranean Europe: An Ecological History (New Haven: Yale University Press)

[6] de Beaulieu J-L, Miras Y, Andrieu-Ponel V and Guiter F 2005 Plant Biosystems 139(2) 114-26

[7] Colombaroli D, Tinner W, van Leeuwen J, Noti R, Vescovi E, Vannière B, Magny M, Schmidt $\mathrm{R}$ and Bugmann H 2009 Journal of Biogeography 36 314-26

[8] Jalut G, Dedoubat J J, Fontugne and Otto T 2009 Quaternary International 200 4-18

[9] Davis B A S, Brewer S, Stevenson A C, Guiot J and Data Contributors 2003 Quaternary Science Reviews 22 1701-16

[10] Harrison S P and Digerfeldt G 1993 Quaternary Science Reviews 12 233-48

[11] Carrión J S, Fuentes N, González-Sampériz P, Sánchez Quirante L, Finlayson J C, Fernández S and Andrade A 2007 Quaternary Science Reviews 26 1455-75

[12] Carrión J S, Fernández S, Jiménez-Moreno G, Fauquette S, Gil-Romera G, González-Sampériz $P$ and Finlayson C 2009 Journal of Arid Environments in press 1-6

[13] Bintliff J 2002 World Archaeology 33(3) 417-35

[14] Prentice I C, Cramer W, Harrison S P, Leemans R, Monserud R A and Solomon A M 1992 Journal of Biogeography 19 117-34

[15] Henkin Z, Seligman N G, Kafkafi U and Prinz D 1998 Plant and Soil 202 317-26

[16] Kosmas C, Danalatos N G and Gerontidis St 2000 Catena 40 3-17

[17] Theodoropoulos T, Reif A and Athanasiadis N 1995 Bot Helv 105 37-54

[18] National Soil Degradation Maps [homepage on the Internet] FAO/UNEP/ISRIC 1990 [updated 2005 December 12; cited 2009 September 17]. Available from: http://www.fao.org/landandwater/agll/glasod/glasodmaps.jsp?country=NER\&search=Displa $\mathrm{y}+\mathrm{map}+\% 21$

[19] Bridges E M and Oldeman L R 1999 Arid Soil Research and Rehabilitation 13 319-25

[20] Montgomery D 2007 Dirt: The erosion of civilizations (Berkeley: University of California Press)

[21] Shiel R S 1999 in Leveau P et al. (eds) Environmental Reconstruction in Mediterranean Landscape Archaeology (Oxbow)

[22] Bruckner H 1990 in Bottema et al. (eds) Man's Role in the Shaping of the Eastern Mediterranean Landscape (Rotterdam: Balkema)

[23] OP-EURI14850 1994 (Luxembourg: European Comission)

[24] van der Leeuw S E and the ARCHAEOMEDES research team 2005 C. R. Geoscience 337 9-27

[25] Kosmas C S 1995 Field site: Spata, Greece, MEDALUS II-Project 1, Basic Field Program, Final Report Covering the Period "1 Janary 1991 to 1 September 1995"

[26] Rother K 1993 Der Mittelmeerraum (Stuttgart: Teubner)

[27] Peyron O, Guiot J, Cheddadi R, Tarasov P, Reille M, de Beaulieu J-L, Bottema S and Andrieu V 1998 Quaternary Research 49 183-96

[28] FAO/IIASA/ISRIC/ISS-CAS/JRC 2009 Harmonized World Soil Database v. 1.1 (Rome: FAO and Laxenburg, Austria: IIASA)

[29] Hijmans R J, Cameron S E, Parra J L, Jones P G and Jarvis A 2005 International Journal of Climatology 25 1965-78

[30] Brooks R H and Corey A T 1964 Hydrology Papers (Fort Collins, CO: Colorado State 
PAGES 1st Young Scientists Meeting (YSM) - 'Retrospective views on our planet's future' IOP Publishing IOP Conf. Series: Earth and Environmental Science 9 (2010) $012011 \quad$ doi:10.1088/1755-1315/9/1/012011

University)

[31] Clapp R B and Hornberger G M 1978 Water Resources Research 14(4) 601-4

[32] Van Genuchten M T 1980 Soil Sci.Soc. Am. J., 4 892-98

[33] Brakensiek D L and Rawls W J 1994 Catena 23 99-110

[34] Saxton K E and Rawls W J 2006 Soil Sci. Soc. Am. J. 70 1569-78

[35] Prentice I C, Sykes M T and Cramer W 1993 Ecological Modelling 65 51-70

[36] New M, Hulme M and Jones P 1999 Journal of Climate 12 829-856

[37] Bohn U, Gollub G and Hettwer C 2000 Karte der natürlichen Vegetation Europas 1 : 2500000 (Bonn-Bad Godesberg, Germany: Bundesamt für Naturschutz)

[38] Webb R S, Rosenzweig C E and Levine E R 1991 A Global Data Set of Soil Particle Size Properties NASA Technical Memorandum 4286 (NASA)

[39] Webb R S, Rosenzweig C E and Levine E R 1993 Global Biogeochemical Cycles 7(1) 97-108

[40] De la Rosa D, Moreno J A, Mayol F and Bonsón T 2000 Agriculture, Ecosystems \& Environment 81(3) 179-90

[41] den Biggelaar C, Rattan L, Wiebe K and Breneman V 2003 Advances in Agronomy, 81 1-48

[42] Larney F J, Janzen H H, Olson B M and Olson 2009 Soil and Tillage Research 103(1) 73-83

[43] Sui Y, Liu X, Jin J, Zhang S, Zhang X, Herbert S J and Ding G 2009 Field Crops Research 111(3) $276-83$ 